\title{
Formulation of the Integrated Information System of River Water Quality in the Cikapundung River, Bandung, Indonesia
}

\author{
Yonik Meilawati Yustiani $^{\# 1}$, Leony Lidya , Toru Matsumoto*, Indriyani Rachman ${ }^{*}$, Imas Komariah* \\ \#Department of Environmental Engineering, Pasundan University \\ Jln. Dr. Setiabudhi 193 Bandung, 40153, Indonesia \\ 11yonik@unpas.ac.id
}

'Department of Informatics Engineering, Pasundan University

Jln. Dr. Setiabudhi 193 Bandung, 40153, Indonesia

\author{
* Department of Live and Environment Engineering, The University of Kitakyushu \\ 1-1 Hibikino, Wakamatsu-ku, Kitakyushu, Fukuoka, 808-0135, Japan
}

\begin{abstract}
Cikapundung River passes through the Bandung City evaluated as heavily polluted river. Many efforts had been conducted by means of various activities. However, those activities are still sporadically conducted, unpublished, and not well-documented, resulting inefficiency of the resources consumption. Therefore, this project aims to formulate a concept of information system which is integrated, suitable, and fulfill the stakeholders needs, enriched with the water quality modeling. For the first step, the method used was best practice analysis by visiting Kitakyushu City to learn how the city monitors the river water quality. The next step was to collect data concerning the potential user or stakeholder types, usage of the information system, and the user's needs. Based on the lesson-learnt method and data collection, it can be concluded that part of Kitakyushu City's river system can be applied to the Cikapundung River system. However, the interaction between users and the information system might be different due to the sensitivity of data publication. Thus a specific step on filtering data prior to publication needs to be placed. Potential users of this system are government officers, researchers, academic staffs, NGO, and the community. Each user has specific characteristic in interact with the system.
\end{abstract}

Keyword- integrated information system, river water quality, Cikapundung River

\section{INTRODUCTION}

There has been increasing awareness of the need for an integrated approach to the management of water resources and the land, largely driven by the world-wide trend in the deterioration of water quantity and quality standards and in increasingly limited access to water[1]. Communities from various institutions are more responsive and care about their environment, especially river and other water bodies.

Bandung City has 46 rivers running through it. Cikapundung River is the most attractive river among those rivers due to its strategic location. This river passes through the most populated area and the famous Bandung landmark. Because of its popularity, the Cikapundung River water quality becomes one great attention of the people and media. Pile of trash covers the Cikapundung River surface after high intensity of rain which causes flood [2], [3]. Cikapundung River crosses the Bandung City approximately $15.61 \mathrm{~km}$ of length.

According to the Bandung City EPA (Environmental Protection Agency) monitoring data, the Cikapundung River water is heavily polluted. Based on the 2014 monitoring data, the parameters exceeding the standard are NH3-N, Fe, Cd, NO2-N, Cu, Pb, BOD, COD, MBAS, Phenol, Oil and Grease. The DO (dissolved oxygen) was also observed lower than the standard in the downstream water. This monitoring data could not be accessed easily. A permission letter needs to be published first by the National Unity, Politics, and Public Protection Division of Bandung City before going to the Bandung City EPA to get the data. The data are recorded in a report book and sometimes cannot directly be copied. This condition makes the analysis and usage of monitoring data not optimal.

In the other hand, several other institutions also conduct Cikapundung River water quality measurement either periodically or occasionally. Many research activities were being conducted concerning the Cikapundung river's improvement efforts, both in the social-economy and engineering aspects [4], [5]. The data are being 
documented in each institution data base. People who are interested in having the data need also permission letter and visit the institution to copy or study the documents.

The unpublished will not give many benefits in term of river water quality improvement. However, not all data might be open to the public freely for several reasons.

This research aims to formulate the appropriate information system to store and publish the Cikapundung River water quality considering the usual procedure. The system will also be equipped with water quality modeling software suitable for the urban river characteristics.

\section{METHODOLOGY}

The Cikapundung River is declared as the icon of Bandung City. Declaration of 'Clean River' was being inaugurated in the river bank of this river in 2011. Figure 1 shows the location of Bandung City, whereas Fig. 2 shows the Cikapundung River location in Bandung City.

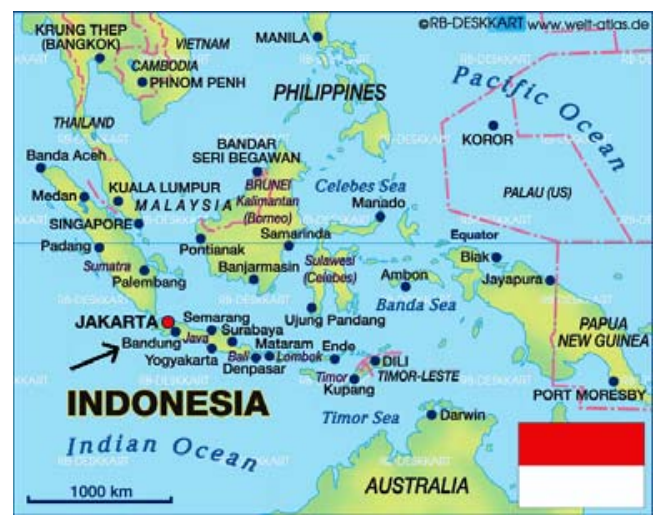

Fig. 1. Bandung City location

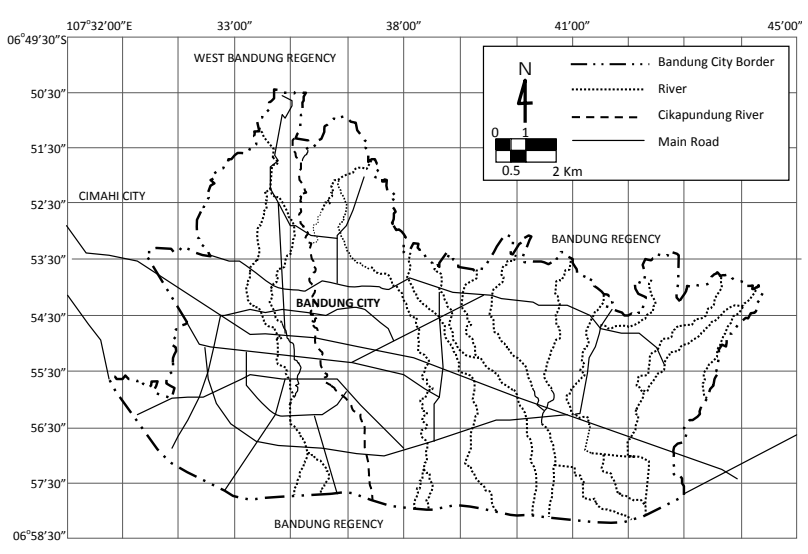

Fig. 2. Cikapundung River location

This research is focused on the segment between Babakan Siliwangi area and Asia Afrika Street. The segment is selected because this segment is the main concern of the Bandung City Government to be rehabilitated.

In this study, an information system was developed by acquiring the potential stakeholders' opinion. Questionnaires were distributed to the local and regional government in order to obtain the system coordinator and river's data management. Besides that, an FGD (focus group discussion) was conducted to gather the opinion of all divisions and sections from the government dealing with river management.

The investigation on the information system integrated with the software was then being formulated, including determination on potential operator, coordinator, and information flow.

Before formulating the information system, an in- depth investigation was conducted to learn how the Kitakyushu City manage to clean the Murasaki River as its main urban river. This investigation was conducting by direct observation and interviewing the Kitakyushu City government. 


\section{RESULT AND DISCUSSION}

Several important points have been observed from the lesson-learnt activity by visiting Kitakyushu City government and Murasaki River. In 1960s, the river was polluted by untreated wastewater of both industrial and domestic activities. It took approximately 30 years to clean the river by conducting many programs. Those important points include:

- $\quad$ Periodically river water quality monitoring

- $\quad$ Intensive water dam monitoring

- Strict law

- Wastewater treatment plan facilitation for every potential pollution source

- Converting raw materials into a more environmental friendly ones

- Application of environmental awareness education for children in the formal schools

- Facilitating the environmental education with interesting museums concerning water, garbage, etc.

- Conducting events for the community involving the river function as a recreational and educational spot.

- Distributing the information concerning the environmental data and issues

Figure 3 shows the water museum spot located in Kitakyushu City. The museum is designed to attract the community, especially children in order to develop their environmental awareness. The elementary school curriculum is enriched with 'on the field' class. The method of the subject on the environmental education was not only given theoretically but also practically.

Stakeholders, who are involved in the river quality management system, belong to institutions and communities. Information system of the river was managed by the government and designed to gives all stakeholders the opportunity to access river data.

Monitoring data of river water quality can be accessed by the public easily under the official website of Kitakyushu City. Therefore, many people can utilize the data optimally for their own purposes.

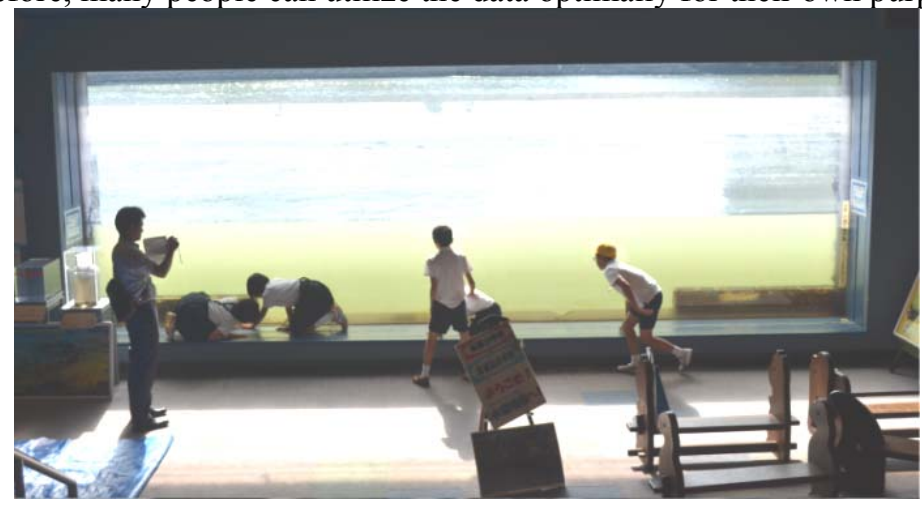

Fig. 3. The elementary students are observing a part of the Murasaki River's long-sectional water ecosystem

Similar to the Murasaki River's stakeholders, the Cikapundung River has many stakeholders, including government, researchers, academia, farmers, traders, tourists, industrial community, residents, NGOs. Those stakeholders are also play as potential users for the proposed information system.

Based on this lesson-learnt activity in Kitakyushu City, generally, Bandung City can apply some methods and systems to improve the water quality of Cikapundung River, including the information system virtually and factually.

In Cikapundung River case, the information system of river water quality and other data considering the river's condition have been gathered by the government are being stored offline in the government institution. Other data collected by scientist, researchers, or public communities were also stored in the collector's storage. Based on the in-depth interviews with stakeholders, all the communities agree to publish those collected data for public. Therefore many parties can utilize the information with their own interest. However, the publication of that information need to be controlled and managed to avoid misusage or publication of un-trusted information.

Figure 4 displays the on-going information system of river water quality data. The numbers in the figure give the sequence flow of data from the laboratory's results to the public. 


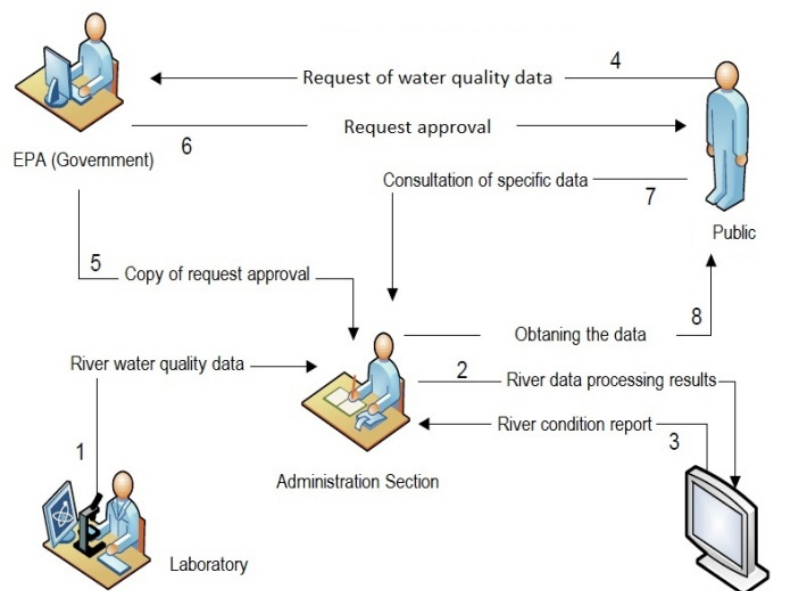

Fig. 4. Sequential flow of river water information and data [6]

The present system reduces the usage of the water quality river information. The public's interest on utilize the data becomes low. This condition may lead to the decreasing of the public awareness of the river condition.

Based on the focus group discussion (FGD) on the river management which had been conducted among the divisions and sections from the government dealing with the river, a flow of information and data can be arranged with specific diagram depicted in Figure 5.

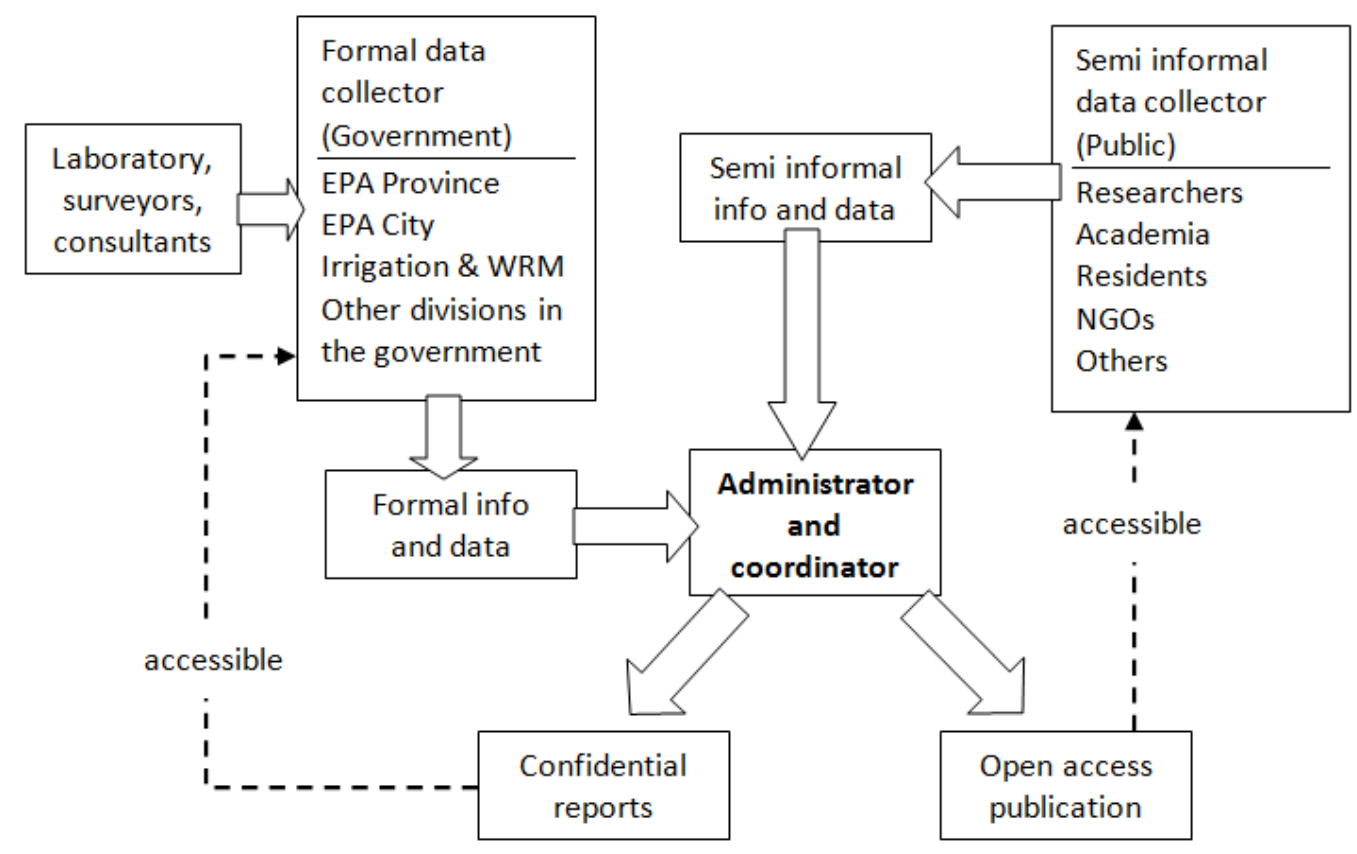

Fig. 5. The proposed flow of information and data of river

Bandung City actually already has a sophisticated command room which can be used for monitor the rivers passing through the city. It can be also utilize as the administrator of information and data flow. Figure 6 shows the command center of Bandung City. 


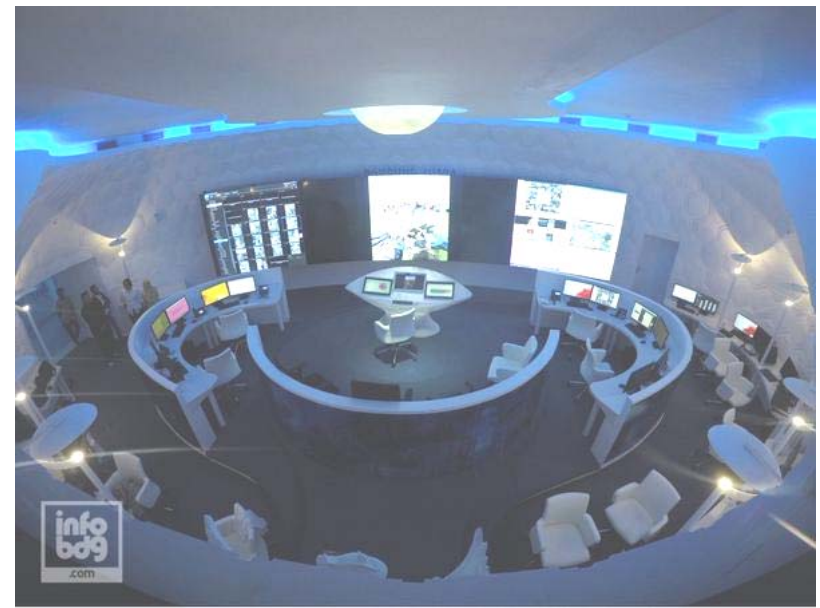

Fig. 6. The command center room of Bandung City [7]

The FGD results appointed the Bandung City EPA (Environmental Protection Agency) to be the administrator and the coordinator of the river water quality information system management. The administrator will gather data not only from the official sources, but also from the semi-informal sources. All the gathered data will not automatically being published openly. The administrator needs to separate and filter data between:

- the trusted from the un-trusted

- the validated from the un-validated

- the necessary from the unnecessary

- the sensitive from the un-sensitive

- etc.

Result of separation and filtration process, the administrator will have 3 kinds of data types, i.e.:

- data that can be published and accessed by the public

- confidential data that can only be accessed by the government

- the junk data that will not be distributed

Due to these separation data accesses, the administrator need also to characteristics for specific in interact with the system.

To make the information system of the river water quality more usable, the interface can be enriched with the special software called KUALA to calculate the water quality for prediction purposes. Figure 7 shows the system architecture of the information system integrated with the software. This software can be downloaded for 'alone' calculation by the public. Results of the calculation will able to be used for its users' purposes. In term of dissemination of calculation, the calculator can also distribute the result for public consumption. The result can even be published in the same information system of the river water quality. In this case, the data will be examined first by the administrator before being openly publish.

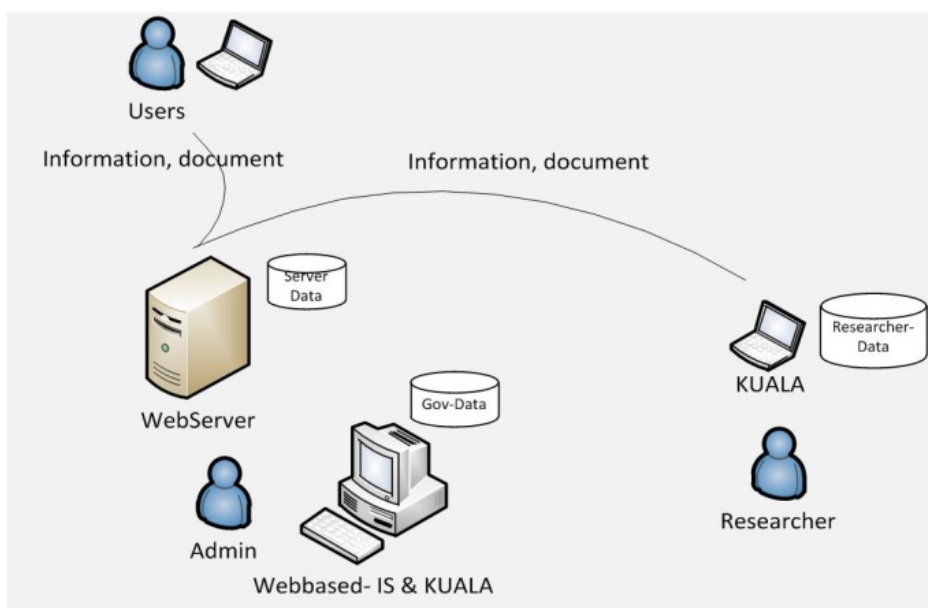

Fig 7. The system architecture of software embedded information system

Based on the questionnaire distributed to the stakeholders, the usage of the information system of the river water quality includes: 
- Determination of the policy

- Verification/confirmation of pollution phenomena

- Prediction of river water quality

- Preparation of the EIA (predicted significant impacts)

- Utilization of river water

\section{CONCLUSION}

Based on the lesson-learnt method and data collection, it can be concluded that part of Kitakyushu City's river system can be applied to the Cikapundung River system. However, the interaction between users and the information system might be different due to the sensitivity of data publication. Thus a specific step on filtering data prior to publication needs to be placed. Appointed administrator is EPA in the Bandung City level.

Potential users of this system are government officers, researchers, academic staffs, NGO, and the community. Each user has specific characteristic in interact with the system.

Enriched information system with KUALA as a useful software can increase the interest of the public to aware more to the river.

\section{ACKNOWLEDGMENT}

This paper was prepared based on the research funded by the Ministry of Research, Technology and Higher Education of the Republic of Indonesia. Facility support was also obtained from the Engineering Faculty of Pasundan University.

\section{REFERENCES}

[1] C. J. M., Hewett, A. Doyle, and P. F. Quinn, Towards a hydroinformatics framework to aid decision making for catchment management. Journal of Hydroinformatics, 12 (2), 2010, pp. 119-139

[2] (http://www.pikiran-rakyat.com/bandung-raya/2016/02/12/360632/sampah-tutupi-sungai-cikapundung), accessed April 2016.

[3] (https://m.tempo.co/read/news/2016/03/31/058758701/sungai-cikapundung-penuh-sampah-ini-jawaban-pemkab-bandung), accessed April 2016.

[4] L. R. Radjabaycolle and Sumardjo, Partisipasi masyarakat terhadap kegiatan pengelolaan Daerah Aliran Sungai Cikapundung di kelurahan Dago Bandung, (In Indonesian) Jurnal Penyuluhan V01. 10 No. 1, 2014, pp. 43-58.

[5] S. H. Djoeffan and D. Mukhsin, Inventarisasi Sarana dan Prasarana Permukiman di Lembah Cikapundung, (In Indonesian) Ethos, Vol. 1 No. 2, 2003, pp. 87-98.

[6] S. D. Rahmawati, B. L. Katjong and E. Khudzaeva, Rancang Bangun Sistem Informasi Spasial Berbasis Web Kualitas Air Sungai (Studi Kasus: DKI Jakarta), (in Indonesian). Studia Informatika: Jurnal Sistem Informasi, 6(2), 2013, 159-170.

[7] Bappeda, Pengelolaan Sungai Bandung. (in Indonesian). Presentation of Ms. Nunun Yanuati on the Workshop of Bandung's River Management, 2016

\section{AUTHOR PROFILE}

Author1 Yonik Meilawati Yustiani has been working for almost 20 years at the Pasundan University. She pursued her doctoral degree in 2004 and now active in research concerning river water management.

Author2 Leony Lidya has been working at the Pasundan University for more than 20 years and interested in research concerning the human-computer interaction.

Author3 Toru Matsumoto is the professor in the Department of Live and Environment Engineering of the University of Kitakyushu. He also actives in many professional and academic forums in Japan.

Author4 Indriyani Rachman is a doctoral student under Prof. T. Matsumoto supervision in the Department of Life and Environment Engineering of the University of Kitakyushu, Japan.

Author5 Imas Komariah is a doctoral student under Prof. T. Matsumoto supervision in the Department of Life and Environment Engineering of the University of Kitakyushu, Japan. 